This is the author's copy of a paper published as:

Watt D (2010). Why men still aren't enough. GLQ: a journal of lesbian and gay studies 16(3):451-464

\title{
WHY MEN STILL AREN'T ENOUGH
}

\section{Diane Watt}

Erotic Discourse and Early English Religious Writing

Lara Farina

New York: Palgrave Macmillan, 2006.

ix +179 pp.

Sodomy, Masculinity, and Law in Medieval Literature: France and England, 1050-1230

William Burgwinkle

Cambridge: Cambridge University Press, 2004

xii +298 pp.

Sexuality and Its Queer Discontents in Middle English Literature

Tison Pugh 
New York: Palgrave Macmillan, 2008

xii +220 pp.

Crossing Borders: Love Between Women in Medieval French and Arabic Literatures

Sahar Amer

Philadephia: University of Pennsylvania Press, 2008

xii $+252 \mathrm{pp}$

In 1993, Speculum, the journal of the Medieval Academy of America, published a special issue entitled “Studying Women: Sex, Gender, Feminism”, edited by Nancy F. Partner. ${ }^{1}$ This special issue was a milestone in medieval studies. It marked, belatedly, institutional recognition of the important contribution feminism and gender studies had made to transforming scholarly understanding of medieval culture over the previous two decades. While Partner voiced her uncertainty about how established feminism had become within academia by that point, she was nevertheless confident that feminist research had "restored to the Middle Ages the substantial reality that human societies consist of two sexes". ${ }^{2}$ Within the special issue, one contribution was by a man: Allen J. Frantzen's provocatively titled "When Women Aren't Enough". ${ }^{3}$ In the opening section of this essay, Frantzen charted the shift from the "women in history" approach to the rise of gender studies, arguing that, following what he saw as the triumph of feminism, "the study of the 'masculine' has become as crucial as the study of the "feminine"." ${ }^{4}$ More than fifteen years later, the debates have moved on, the terminology and theoretical frameworks have changed, and the victories of 
feminism seem short-lived. The major developments of the past two decades that have transformed our understanding of medieval culture and society have been the growth of the history of sexuality as a (sub-)discipline in its own right, and the impact of queer theory on literary criticism. As Frantzen predicted so accurately, the study of men and masculinity has been central to these new movements. In the process, however, women and femininity have, I argue here, become sidelined once again. Increasingly the terminology of both the history of sexuality and queer theory has become gender exclusive: homosexuality has come to mean, in common academic usage, male homosexuality; gay history is gay male history; queer sexualities are all too often queer male sexualities. Women are not given equal weight to men, and the histories of male and female sexualities are still artificially separated.

In surveying recent studies of medieval sexualities, the extent of this divide becomes clear. While three of the four titles discussed here complicate this picture of a divided history, they do not negate it. The first, Lara Farina's Erotic Discourse and Early English Religious Writing, is conscious from its inception of the need to think about gender and sexuality in inclusive and fluid terms, but remains ambivalent in its relationship to queer studies. William Burgwinkle's Sodomy, Masculinity, and Law in Medieval Literature: France and England, 1050-1230 is almost exclusively concerned with male sodomy, although, importantly, it does offer one of the first sustained queer readings of the work of Marie de France. The third study, Tison Pugh's Sexuality and Its Queer Discontents in Middle English Literature, is primarily interested in queer masculinities and male literary characters, although one female character becomes a central focus of analysis: Griselda in Chaucer's Clerk's Tale. As a counterpoint, Sahar Amer's Crossing Borders: Love Between Women in Medieval French and Arabic Literatures is concerned solely with the representation of lesbians. This is, 
nevertheless, justifiable. As Amer points out, “A literary history of medieval lesbianism has yet to be written" (3). There remains a lacuna in the study of medieval culture, which scholarship such as that found in Francesca Canadé Sautman and Pamela Sheingorn's ground-breaking edited collection, Same Sex Love and Desire Among Women in the Middle Ages, has only begun to fill. ${ }^{5}$ There is no medieval equivalent to Valerie Traub's The Renaissance of Lesbianism in Early Modern England. ${ }^{6}$

While to varying extents, these four studies maintain separate gendered histories, what unites them is a common desire to push against some of the limitations and boundaries of the disciplines within which they situate themselves: whether medieval studies, the history of sexuality, or queer and gender theory. Scholars working within medieval studies, in particular those interested in the histories of sexuality and gender, have begun to challenge traditional teleologies and period boundaries, and it is Farina's contribution to these debates that is particularly innovative. At the same time, within queer studies, the exclusive association of queer with non-"normative" and transgressive or subversive sexualities has been questioned, and Pugh's book considers the implications of this in offering his new readings of canonical Middle English literature. Both medieval studies and the history of sexuality have also seen a recent turn towards what Amer calls "cross-cultural comparative research" (165). Burgwinkle's and Amer's research, which acknowledges the multiculturalism and porous geographical, political, religious, linguistic and cultural boundaries of medieval societies, can be situated within this development.

The study of English Literature remains beset by restrictive notions of periodization, which often get in the way of our ability as scholars to see the bigger picture, whether that be in 
relation to devotional writings and practices, to religious expression, to women's engagement with literary culture, or to the history of sexuality. Lara Farina's Erotic Discourse and Early English Religious Writing sets out to challenge one of the most significant divisions by exploring texts written both before and after the Norman Conquest. In linguistic terms the Conquest marked a major shift in the vernaculars from Old English to Anglo-Norman (now often, and not un-problematically, referred to as the "French of England"7) and Middle English, although Latin as a language of religion and high culture remained a constant before and after 1066. But the impact of the Norman invasion was much greater than this change in languages suggests, and it had far reaching implications in terms of politics, society, religion, literature, and gender and sexuality. Anglo-Saxon literary and historical scholarship has been resistant to acknowledging the evidence in the extant written sources of sexuality, and historians of sexuality and their literary equivalents have paid little attention to pre-eleventh century materials. In analyzing one tenth-century religious text- the poetic sequence known as Christ I - alongside later, twelfth- and thirteenth-century devotional works-Ancrene Wisse (a guide for anchoresses), the "Wooing Group" (a series of prose prayers), and Thomas of Hales's poem Love Ron-Farina demonstrates that a vernacular tradition of erotic affectivity began much earlier than has generally been recognized, and that it crossed the cultural divide between Anglo-Saxon and post-Conquest England.

To modern readers (with the obvious exception of those interested in psychoanalysis and familiar with the process of sublimation) the idea that the religious and the sexual might be intimately connected can seem quite alien, but as Lara Farina points out, in the thinking of a number of later medieval European theologians "erotic fantasy was acknowledged to be both 
a tool for refining religious disposition and a condition, an episteme, fundamental for acquiring knowledge of God." (3). Farina sees her study as contributing both to the history of sexuality and the history of reading, and it is the originality of this approach that makes Erotic Discourse so important. Farina explains early on in her introduction that she has chosen the term "erotic" to describe not the representation of sexual identities, acts or desires within a text but "a relation between readers and texts" (2). As Farina puts it: "Although I discuss images that had an erotic resonance for medieval readers, the texts that offer this imagery do more than portray sexualized subjects; they also prompt their readers to participate in sensual and sexualized practices of their own" (2). In other words these devotional texts, and others like them, require of their readers certain bodily as well as intellectual and/or emotional responses. At the same time, the texts actively engage with the social spaces within which the acts of reading will take place, whether communal and shared or solitary and private. Thus the guide for anchoresses, Ancrene Wisse, encourages and simultaneously attempts to control, within the dangerously feminized and secretive space of the anchorhold, an active readerly engagement with its amatory tropes and erotic language.

Although Farina recognizes the importance of Foucault to scholarship on medieval sexuality, in identifying some of the main difficulties in the application of Foucauldian paradigms to the discursive structures of the Middle Ages, she distances her own study from such an approach. Indeed Erotic Discourse does not define itself as a queer book and on occasion it almost selfconsciously shies away from queer readings. Thus, in her second chapter, "Dirty Words: Ancrene Wisse and the Sexual Interior", Farina cites the text's use of the Biblical example of Dinah who "eode ut to bihalden uncuđe wummen ... [ant] ha leas hire meidenhad \& wes imaket hore" [went out to look at strange women ... [and] she lost her maidenhood and was 
made a whore] (quoted and translated on page 45). Although Farina notes that the "lurking sexual threat" here described does not initially appear to be heterosexual, she does not develop this line of thought. By failing to comment on the fact that, at least fleetingly, the text evokes the idea of female same-sex desire, one potentially fascinating line of further enquiry is effectively closed down. Likewise, in the third chapter, "Mystical Desire, Erotic Economy, and the Wooing Group", Farina discusses the reversal of gender roles in the prayers of the "Wooing Group", in which the speaking persona is given an agency usually restricted to the male. Farina recognizes the potentiality of this troubling of gender norms for the texts' female audience: "The challenge to binary gender paradigms might be seen as transgressive, even 'queer' in the sense of exposing gender categories as provisional, incomplete, and politically motivated" (77). Nevertheless, shortly afterwards Farina retreats from this position, concluding that any sense of empowerment is illusory, and that the readers of these prayers "are, after all, still being defined by their place in the social network of marriage arrangements" (78).

In terms of its contribution to the history of sexuality, Erotic Discourse can be usefully read alongside the large body of scholarship by historians and critics such as E. Ann Matter, Bruce Holsinger, and Karma Lochrie which explores same-sex desire in the work of later medieval female mystics; ${ }^{8}$ or the much smaller corpus on pre-Conquest sexualities, which includes significant interventions by Frantzen, Clare A. Lees, and, more recently, Carol Braun Pasternack and Lisa M.C. Weston. ${ }^{9}$ As outlined above, the readers of Farina's texts, lay or monastic, women or men, are defined by their bodily responses to the devotional literature they encounter. Thus, as Farina explains on the very first page, these "strange" reading bodies "defy easy identification with the fixed categories of male or female, heterosexual or 
homosexual, singular or shared" (1). In summary, as Farina's analysis makes clear, the readers of these rather queer religious texts occupy queer subject positions and queer spaces, and are encouraged to derive queer pleasures from the act of reading. Thus, even if Erotic Discourse does not define itself in these terms, there is still something very queer about Farina's approach to understanding devotional reading in the Middle Ages.

William Burgwinkle's study of masculinity and sodomy is much more explicitly concerned with offering queer readings of medieval literary material. It crosses geographic and political boundaries (between England and France) rather than temporal or linguistic boundaries. It also crosses generic boundaries in so far as the first two chapters, surveying the ways in which "sodomy was recognized, located, diagnosed, theorized, and imagined in texts from the mid-eleventh to the early thirteen century" (1), look at a wide range of sources from theological writings, physiological treatises and chronicles to letters and even medieval graffiti. The second section, in contrast, goes on concentrate on the three more literary texts or groups of texts that are its main focus: the Grail legends; the Lais of Marie de France; and Alain de Lille's dream vision, De planctu naturae. At the heart of Sodomy, Masculinity, and Law in Medieval Literature, then, is a chapter on a female aristocrat writing for the English court of Henry II, husband of the great literary patron Eleanor of Aquitaine. Marie de France is a fascinating and enigmatic figure, and there are various theories about her identity, including the popular one that she was Henry II's half sister. Why is Marie de France so important to Burgwinkle? First, Marie de France's Lais, with all their inherent moral ambiguity, problematize dominant ideas of marriage and courtly love, and question traditional medieval gender roles. Indeed, Burgwinkle concludes the chapter with the assertion that "Few medieval authors went so far in constructing a queer love story as did 
Marie de France" (169). Second, Burgwinkle is drawn to Marie de France because she seems to offer a model for queer reading (akin to that which Burgwinkle himself adopts), or at any rate to require an approach to reading that is engaged, questioning, even disruptive. As Burgwinkle explains, in the prologue to the Lais that appears in the most complete surviving collection (London, British Library, MS Harley 978), Marie de France offers an "interactive model of interpretation" (138). She invites her readers to collaborate in the production of meaning: "it is the reader who brings to the text his/her own experience and thus the text's own 'surplus"' (138). Burgwinkle goes on to make a connection between Marie de France as author and the first protagonist in the collection as it is found in the Harley manuscript: Guigemar. Guigemar's story is preceded in the Harley manuscript by a second prologue in which Marie de France reflects bitterly on the spiteful gossip that threatens those whose abilities and success have gained them a good reputation. Guigemar's own narrative is that of a virtuous knight who suffers because of the maliciousness of others. In Guigemar's case, the slander focuses on his lack of interest in women; in Marie de France's case, perhaps, it is her gender transgression as a woman writer (one of the first in the English tradition, no less) that is so disruptive. As Burgwinkle states later, Marie de France is "a twelfth-century anomaly, a highly literate woman writing in open competition with men" (149).

In this chapter on Marie de France, Burgwinkle offers a detailed reading of Guigemar, drawing out parallels between this troubled knight and the Ovidian figure of Narcissus, and also finding traces within the narrative of earlier traditions of Celtic male homoeroticism. He follows this with a survey of troubled gender narratives in the Lais as a whole, and concludes by discussing Lanval (in which Guinevere embarks on a homophobic attack on the protagonist) and Bisclavret (which tells of a werewolf who is exiled from and then welcomed 
back into the homosocial court of his king). Burgwinkle makes only passing reference to Eliduc, the final lai in the Harley manuscript, even though he does note that "even a cursory reading" reveals its transgressive potential (149-150). In this tale, Eliduc finds himself married to one woman, Guildelüec, while in love with another, Guilliadun. This is not, however, a story about conflict between women, but about reconciliation and devotion: when Guilliadun discovers Eliduc is already married she collapses, and it is Guildelüec who restores her to life, and who then resolves to retire to a convent so that her husband can marry her rival. Ultimately, however, it is the two women who are united in the convent, while Eliduc enters a monastic order. For Burgwinkle, this "must be read as a critique of heterosexuality as well as marriage" (50) but it is also much more. Judith M. Bennett's important formulation "lesbian-like" is useful in here, because of its flexibility and range. ${ }^{10}$ According to Bennett, "If women's primary emotions were directed toward other women, regardless of their own sexual practices, perhaps their affection was lesbian-like. If women lived in single-sex communities, their life circumstances might be usefully conceptualized as lesbian-like. If women resisted marriage, or indeed, just did not marry, whatever their reason, their singleness can be seen as lesbian-like... And if women ... otherwise flouted norms of sexual propriety, we might see their deviance as lesbian-like." Guildelüec and Guilliadun is certainly lesbian-like, according to this definition. Indeed, if at the beginning of the Lais we are invited by the author to see connections between Guigemar and Marie, by the end, the connection seems to be with Guildelüec and Guilliadun. This Marie de France is not only queer; she is herself lesbian-like.

The limitations of Burgwinkle's approach to Marie de France's Eliduc are indicative of some of the more significant blind-spots in his otherwise lively and highly engaging study. His 
terminology is at times somewhat ill- or problematically defined. Thus he acknowledges that the "Law" referred to in the title of the book is "perhaps excessively broad" and that he uses the word in the sense of "any sort of regulation by which communities establish standards and norms" and also "the internalized laws of exchange, prohibition, and development by which subjectivity, gender, and status are determined" (3). Conversely, it might be argued that Burgwinkle's definitions of both "sodomy" and "masculinity" are excessively narrow because in both cases they exclude the female. In the medieval period, sodomy was understood to be a sin that could be committed by women as well as men, and although as a category it might indeed be thought of as "utterly confused", sex between women was included within it. Likewise the notion of the virago or the manly woman is found in a variety of medieval sources including medical treatises. Furthermore, ever since the publication over a decade ago of Judith Halberstam's influential Female Masculinity (which Burgwinkle does not refer to in his text or bibliography) queer feminist critics, including queer feminist medievalists, have increasingly questioned the critical assumption that masculinity is the preserve of the male. ${ }^{12}$ Nevertheless, Burgwinkle assumes that the medieval sodomite was "generally male" and justifies his decision to concentrate "almost exclusively on men" as follows: "partly because I want to establish how crucial the invention of sodomy was to the institution of a new model of heroic and highly monitored masculinity in the twelfth century, and partly because the texts themselves, even when penitential, only very rarely allude to female sodomites" (2). As a result of his anachronistic use of his terminology, Burgwinkle finds himself struggling with his source material, most notably when he cites as an example of medieval homophobia the Livre des manières, an early work of estates literature, written by the Anglo-Norman bishop Etienne de Fougères and dedicated to the countess of Hereford. Burgwinkle acknowledges that Etienne is actually describing sex between women but passes over this inconvenient point very quickly, concluding that "the terms in which he condemns 
such behaviour can easily be extended to males as well" (8). Yet Etienne's work, with its seven stanzas devoted to lesbianism, is not quite the exception that Burgwinkle claims it to be, and, even if this did require Burgwinkle to extend the time-frame of his study, a strong case can be made for the inclusion of some other famous examples of medieval French texts that address female sodomy and/or masculinity and heroism, most notably the Chanson d'Yde et Olive and the Roman de Silence. To place Yde and Silence alongside Perceval, Guigemar, Lanval, Bisclavret and Alain de Lille's Nature, Venus and Genius, would serve only to queer further sodomy, masculinity and the law.

Unlike Farina and Burgwinkle, Tison Pugh in his Sexuality and Its Queer Discontents does not query temporal, geographical, linguistic or generic borders. Rather he works firmly within the established boundaries of Middle English literature addressing canonical worksnamely Pearl and The Canterbury Tales--alongside the less familiar romances Amis and Amiloun and Eger and Grime. Nevertheless, Pugh can also be seen to be challenging the limitations of literary studies; in this case the self-imposed restrictions of many queer readings. Pugh is interested in the question "what makes a text queer?" and he addresses it by focusing on medieval texts that ostensibly do not depict sodomitical acts or same-sex sexual desires. Thus Pugh turns our focus away from Chaucer's Pardoner, or the Pearl-poet's account of Sodom and Gomorrah in Purity, and the same author's portrayal of homosocial kisses in Sir Gawain and the Green Knight, and redirects it onto Harry Bailly, Griselda and Walter, the Pearl-dreamer and God himself, and the eponymous heroes of the two romances. As Pugh explains: "This study participates in [...] an expansive view of the queer" in that all of the protagonists whom he analyses are "ideologically queered from the masculine privilege of western society precisely because their gendered identities and sexual desires are rendered 
suspect in the manner congruent to the construction of the sexually queer" (7). Although these figures represent what we might think of as "normative" sexualities (Pugh is however fully aware of the arguments put forward by Karma Lochrie and James A. Schultz that medieval and modern ideas of normative are considerably different), ${ }^{13}$ in their different ways, or so Pugh contends, they all trouble hegemonic patriarchal ideology. This is not to say that they do so to the same effect: as Pugh notes, queerness is not in itself subversive, but rather “it rebels against ideological identity codes in some instances while quelling such resistance under other circumstances" (3). Indeed, for Pugh, compulsory queerness is intrinsic to heterosexuality. In his final analysis, none of Pugh's characters subverts the status quo; all are "ultimately rendered queerly normative" (15).

In providing an example of what he calls "the vast lability of normativity" (9) Pugh cites the example of the spiritual marriage, a form of sanctified medieval marriage where the couple remain chaste as an expression of their devotion to God. Pugh contends that such marriages "register either as normative or as queer depending upon the circumstances of their enactment of heterosexuality" (9) and to illustrate this he considers the examples of Cecilia and Valerian in Chaucer's Second Nun's Tale (which Pugh sees as normative) and Margery Kempe and her husband John in The Book of Margery Kempe (which he sees as queer). Despite Margery Kempe's agency, it is John Kempe who is "queered from his patriarchal privilege" by his reluctant vow of celibacy (9). In considering the role of the female, Pugh, like Burgwinkle, might also have benefitted from using the term lesbian-like (which he coincidentally cites in a different context on the next page), in this case to describe the subversively queer possibilities that spiritual marriage offered women from the Anglo-Saxon age - the example of Aethelthryth of Ely comes to mind - to the end of the Middle Ages. 
The limitations of Pugh's approach when applied to female agents is further illustrated in his second chapter “Abandoning Desires, Desiring Readers, and the Divinely Queer Triangle of Pearl'. Here Pugh adapts the late Eve Kosofsky Sedwick's formulations in Between Men concerning homoerotic rivalry and male bonding to explain the theologically-sanctioned desire for the divine that emerges from the competition between the Dreamer and God over the Dreamer's lost pearl. ${ }^{14}$ Taking this further, Pugh suggests that the reader of the poem identifies with the Dreamer's initial confusion and subsequent comprehension and thus "the divinely queer triangle of Dreamer, Pearl Maiden, and God has as its metatextual equivalent the narratival erotic triangle of reader, Pearl, and author" (29). In this reading, once again, it is the male (human and divine) that is queered, and the reader, in being equated with the Dreamer, is also assumed to be male, or at least to identify as male. The Pearl Maiden remains simply an object of exchange. Yet in the poem itself, the Pearl plays an active role as the Dreamer's instructor, and in so doing she troubles Pugh's interpretation. Like generations of critics before him, Pugh seems unsettled by "this amorphous character" (36) pointing out that she could conceivably represent the Dreamer's mother, wife or daughter, but that she does not define her relationship with the Dreamer with any greater precision. What seems to be really troubling here is simply that the Pearl Maiden refuses to define her relationship with men. The model of the spiritual marriage could be helpfully applied once more: the Pearl, whatever her relationship with the Dreamer on earth, is now married to Christ. The (after-)life she has chosen (or been chosen for) is lesbian-like, and she has been removed from a masculine economy in which she can be controlled by her father, husband, or even son. The lesbian, or lesbian-like reader, might chose to identify, not with the Dreamer, but with the Pearl herself, and such a reader might also find that there is indeed something queer in the Pearl's own sexuality, as her very name suggests. 
In contrast to the treatment of Pearl, the agency of the female protagonist of Chaucer's Clerk's Tale is given far more attention. Griselda, like Margery Kempe, is responsible for queering her husband, although this works in a quite different way. Whereas for Burgwinkle the masculine is equated with the male, Pugh acknowledges female masculinity, arguing that it is manifested in Griselda's monstrously passive endurance of suffering. As he puts it: "it takes balls — queer balls — to be such a faithful wife" (90). Griselda, Pugh claims, demonstrates what he calls a "queer fidelity" to her tyrannical husband Walter. By queer fidelity, Pugh means when an individual participates in and maintains "social systems and cultural arrangements directly antithetical to one's own interests ... e.g., women in ultraconservative and patriarchal religions, Log Cabin Republicans" (79). How useful is it to stretch the already fluid use of the term queer to describe the sort of phenomena to which Pugh is referring, which support rather than subvert the dominant ideology? According to this line of thinking, Sarah Palin would be queer; or to find an example that is closer to that which Pugh uses, the battered wife who returns repeatedly to her husband demonstrates "queer fidelity". While many readers would agree that the tale's horrific depiction of the effects of pushing passive femininity beyond all limits demonstrates the undesirability of such a gender ideal, they would not necessarily accept that it thus undermines the ideological systems that have created it. To put this another way, Pedro Almodóvar's troubling and transgressive depiction of domestic violence in Pepi, Luci, Bom (1980) is queer. Chaucer's Wife of Bath's account of her differently abusive marriages may be queer. Chaucer's Clerk's portrayal of Griselda and Walter is not. Pugh is on much safer ground when he focuses on the queering of his male heroes or anti-heroes. Particularly invigorating is his reading of the hypermasculine host of the Canterbury pilgrimage, Harry Bailly, who at the beginning of the storytelling competition appears as an aggressive and homophobic alpha-male, but who, as the 
competition progresses, gradually loses his authority and finds that it is his own masculinity that has been queered. Here Pugh demonstrates convincingly the potential of the queer to quell rather than to instigate insurgence: "With the pilgrimage's leading social climber tamed of his rebellious and gendered puissance, queerness reveals its ideological power to create masculine subjects appropriate to their social caste" (73).

The title of Sahar Amer's study, Crossing Borders: Love Between Women in Medieval French and Arabic Literatures, firmly locates it within a tradition of lesbian rather than queer studies. This is not to say that Amer rejects the term "queer" although she is silently resistant to its appropriation for use in a solely male context. Refreshingly, the index entry for "queer studies: developments in queer theory" actually leads the reader to a discussion of new directions in lesbian studies. Throughout this study, Amer uses the words "lesbian" and "lesbianism", without quotation marks, or italics (the practice favoured by Traub), in place of the formulations "same-sex desire among women", "female same-sex desire", and "same-sex sexual acts among women" that are more widely accepted in pre- and early modern studies. Amer's use of lesbian is close to Bennett's lesbian-like (and she applies it in similar contexts) but lesbian trips off the tongue more easily. Amer has a theoretical point to make: the various circumlocutions that are used in contemporary scholarship in place of lesbian "end up maintaining medieval lesbians in othered categories of time and culture" (9). Even if, in the Christian Middle Ages, the use of lesbian to describe same-sex relations between women is not widespread, and never after the tenth-century, the same cannot be said for the Muslim world, where the terms sahq and sahiqa, denoting 'lesbianism' and 'lesbian', are found in a range of writings and contexts. Perhaps the most remarkable consequence of Amer's study 
is that it makes very clear that the rejection of the word "lesbian" in a medieval context is not over-cautious, but Orientalist.

In the opening chapters of Crossing Borders, Amer also addresses the representation of lesbianism in the medieval Arabic erotic tradition, looking at texts such as Ibn Nasr alKatib's tenth-century Encyclopedia of Pleasure (which includes the story of "the first lesbian couple" (18) a Christian Princess and her Arab beloved); al-Jurjani's eleventh-century Anthology of Metonymic Devices Used by the Literati and Allusions in Eloquent Speech; alTifashi's thirteenth-century The Delight of Hearts; Ibn Falita's An Intelligent Man's Guide to the Art of Coition; and of course the One Thousand and One Nights (in particular The Story of Qamar al-Zaman and Princess Boudour). Amer's argument is that these medieval Arabic writings on sexuality, with their often positive descriptions of lesbianism, had a demonstrable influence on the representation of female same-sex desire in medieval French texts, such as the Livre des manières (mentioned above in my discussion of Burgwinkle's book), Yde et Olive, and Jean Renart's Escoufle. While Amer's analyses of her French texts are indebted to previous, acknowledged, interpretations, it is her emphasis on the way the Arabic texts resonate through these Western literary works that is so innovative. For Amer, the crossdressing, woman-loving hero/ine Yde becomes "a Western Scheherazade who, like her Eastern counterpart, stands as a prime example of female empowerment achieved through sexual knowledge" (75-76).

In conclusion, I want to return to the fascinating opening chapter of Crossing Borders, in which Amer outlines her theoretical and methodological approach and provides an overview of her sources, because it is here that Amer discusses the difficulties she faced in accessing 
her primary materials. Two texts proved particularly difficult to locate: the Arab text of the Encyclopedia of Pleasure and an English translation of The Delight of Hearts. During a research trip to Egypt, Amer discovered that booksellers refused to sell her the Encyclopedia of Pleasure because she was a Muslim woman. She subsequently found that the Arabic edition of the text was more readily available in specialist European bookstores. Nevertheless, even after obtaining a copy in the States through the intercession of an Arab male friend, she discovered that the book itself had been crudely but fairly effectively censored, and furthermore that it did not contain several chapters, including those on samesex sexuality. Obtaining the English translation of The Delight of Hearts brought different problems. Publishing with a male gay press, the translator, Edward A. Lacey, decided to include only the sections of male same-sex sexuality, and thus omitted the chapter on lesbianism as well as other material on heterosexual sex. This is a different kind of censorship, but it is a censorship of sorts. Amer notes that the Lacey translation "presented sexual divisions that were certainly not present in the medieval text" at this same time as it "utterly erased lesbian voices in the medieval Arabic tradition" (27).

The point to take from this narrative is that the problems scholars face in trying to access the sources for the history of lesbianism are pervasive. In her conclusion entitled "Beyond Orientalist Presuppositions", Amer makes it very clear that the subjects of her study are "twice marginal, twice invisible" (to adapt Jacqueline Murray’s formulation to a non-Western context). ${ }^{15}$ Amer's study forces its readers to question twenty-first century assumptions about women in the medieval Islamic world, and about the assumed "absence" of lesbians in medieval history and culture. In the ongoing process of writing the history of lesbianism, new source material is continually being re-discovered, and new theoretical and methodological 
frameworks are being developed. Scholars have to continue to push against the boundaries of their disciplines, and to think across period and cultural divisions. At the same time, it is crucial that scholars do not follow the example of the English translator of The Delight of Hearts; that in opening up their source materials to a wider audience, they do not create new, artificial—and sometimes anachronistic--restrictions and limitations; that in thinking about sodomy and masculinity, for example, women (the lesbian, the virago) are not excluded. When it comes to writing the histories and literary histories of sexuality, men still aren't enough.

\footnotetext{
${ }^{1}$ Speculum 68.2 (1993). Special Issue on “Studying Women: Sex, Gender, Feminism”.

${ }^{2}$ Nancy F. Partner, “Introduction,” 305.

${ }^{3}$ Allen J. Frantzen, “When Women Aren’t Enough,” Speculum 68.2 (1993), 445-471.

${ }^{4}$ Frantzen, "When Women Aren't Enough,” 451.

${ }^{5}$ Francesca Canadé Sautman and Pamela Sheingorn, eds., Same Sex Love and Desire Among
} Women in the Middle Ages (New York: Palgrave, 2001)

${ }^{6}$ Valerie Traub, The Renaissance of Lesbianism in Early Modern England (Cambridge:

Cambridge University Press, 2002).

${ }^{7}$ The term does not adequately describe the use of French in Ireland, Scotland and Wales in this period.

${ }^{8}$ E. Ann Matter, "My Sister, My Spouse: Woman-Identified Women in Medieval Christianity," Journal of Feminist Studies in Religion 2.2 (1986): 81-93; Bruce Holsinger, "The Flesh of the Voice: Embodiment and the Homoerotics of Devotion in the Music of Hildegarde of Bingen (1098-1179)," Signs 19.1 (1993): 92-125; and Karma Lochrie, "Mystical Acts, Queer Tendencies" in Constructing Medieval Sexuality, ed. Karma Lochrie, Peggy McCracken, and James A. Schultz (Minneapolis: University of Minnesota Press, 
1997), 180-200. These are simply representative examples of an extensive body of work in this area.

${ }^{9}$ Allen J. Frantzen, Before the Closet: Same-Sex Love from Beowulf to Angels in America (Chicago: University of Chicago Press, 2000); Clare. A. Lees, "Sex, Bodies, and Spirituality in Anglo-Saxon Culture," The Journal of Medieval and Early Modern Studies 27.1 (1997): 17-45; and Carol Braun Pasternack, and Lisa M.C. Weston, eds., Sex and Sexuality in AngloSaxon England (Tempe, AZ: Arizona Centre for Medieval and Renaissance Studies, 2004).

${ }^{10}$ Judith M. Bennett, "'Lesbian-Like' and the Social History of Lesbianisms,” Journal of the History of Sexuality 9.1-2 (2000): 1-124.

${ }^{11}$ Bennett, “'Lesbian-Like,” 15.

${ }^{12}$ Judith Halberstam, Female Masculinity (London: Duke University Press, 1998).

${ }^{13}$ Karma Lochrie, Heterosyncrasies: Female Sexuality When Normal Wasn't (Minneapolis: University of Minnesota Press, 2005); and James A. Schultz, Courtly Love, the Love of Courtliness, and the History of Sexuality (Chicago: University of Chicago Press, 2006).

${ }^{14}$ Eve Kosofsky Sedgwick, Between Men: English Literature and Male Homosocial Desire (New York: Columbia University Press), 1985.

${ }^{15}$ Jacqueline Murray, "Twice Marginal and Twice Invisible" in The Handbook of Medieval Sexuality, ed. Vern L. Bullough and James Brundage (New York: Garland, 1996), 191-222. 